\title{
Ethanol Production from Waste of Cassava Processing
}

\author{
Daiana G. Martinez ${ }^{1, *}$, Armin Feiden ${ }^{1}$, Reinaldo Bariccatti ${ }^{1}$ and Katya Regina de Freitas Zara ${ }^{2}$ \\ 1 Energy in Agriculture Engineering Department, State University of West Parana, \\ Cascavel 85819-110, PR, Brazil; armin.feiden@gmail.com (A.F.); bariccatti@yahoo.com.br (R.B.) \\ 2 Federal University of Latin American Integration, Foz do Iguaçu 85866-000, PR, Brazil; \\ katya.freitas@unila.edu.br \\ * Correspondence: daiana.gmartinez@yahoo.com.br; Tel.: +55-045-999202928
}

Received: 27 July 2018; Accepted: 13 September 2018; Published: 5 November 2018

\begin{abstract}
Cassava processing produces by-products such as brown bark, between bark, disposal, bran, fiber and bagasse. Cassava bagasse is characterized as a source of starch that can be converted into sugars to obtain biofuels. The objective of this work was to produce ethanol from this cassava processing residue and to evaluate its contribution potential in the Brazilian energy matrix. Cassava processing residues were obtained from four different starch manufacturers in Brazil. Analysis of the chemical compositions of these samples provided the content of starch, sugar, crude grease, moisture, ash and also their $\mathrm{pH}$ values. For the ethanol process, the samples were submitted to enzymatic hydrolysis using the alpha-amylase and amyloglucosidases enzymes, followed by fermentation and distillation. The samples showed high starch indices, approximately $64 \%$ on average. The average yield of ethanol obtained was 30\% after treatment of the sample like this. Considering the estimated volume of cassava bagasse in Brazil, it is possible to produce an average of 789 million cubic meters per bagasse, replacing about $24 \%$ of the first generation ethanol. Cassava bagasse can be considered an interesting biomass for the production of biofuels, contributing to the expansion of the energy matrix.
\end{abstract}

Keywords: biofuel; second generation ethanol; cassava bagasse

\section{Introduction}

Cassava bagasse is an inexpensive and broadly available waste by-product from cassava starch production. It contains roughly $50 \%$ cassava starch along with mostly fiber and could be a valuable feedstock for various bioproducts [1]. Cassava pulp or bagasse is a byproduct of starch production.

For each 250-300 tons of cassava root processed, about 280 tons of bagasse with $85 \%$ moisture are produced [2]. Currently, the majority of the cassava bagasse is discarded as waste; however, this residue can be considered as an excellent source of fermentation for higher-value biochemicals [3], as is the case with second generation ethanol.

Second generation ethanol production is a strategic alternative to increasing ethanol production with environmental and economic advantages. Because of this, there is currently great interest in developing technologies for obtaining cellulosic ethanol (second generation) from the conversion of cellulose and hemicellulose of the bagasse [4] Great effort has been employed on the study of the enzymatic hydrolysis of sugarcane bagasse and many different pre-treatment methods were studied to enhance itsbiodigestibility by enzymes [5].

The use of lignocellulosic materials as feedstock for second generation bioethanol production has not yet become an industrial reality due to the lack of efficient and low cost technologies, which results in prohibitive investment and production costs as well as poor returns on investment [6].

Increased production and use of ethanol with emphasis on advanced biofuels participation (such as cellulosic ethanol, also known as second-generation or $2 \mathrm{G}$ ) is a commitment recognized by many 
countries in the world, including the Brazilian Government in its Intended Nationally Determined Contribution (INDC) to United Nations Conference on Climate Change-COP 21 [7].

Therefore, potential environmental benefits of different alternatives for $2 \mathrm{G}$ ethanol production should be properly quantified for supporting public policy formulation that will affect the future of climate and other environmental aspects of our planet [8].

The results obtained from the test were applied to verify the production potential in Brazil. According to [9] each ton of manioc processed about $930 \mathrm{~kg}$ of manioc bagasse was produced, so it was possible to obtain a survey of the Brazilian Ministry of Agriculture and Supply related to cassava production between 2017 and 2018 to estimate the second-generation ethanol production potential from cassava bagasse. Subsequently, this value was compared to the data expressed by EPE-Energy Research Company (2018), where they present the volume of ethanol produced in 2017.

In this context, the objective of this study was to analyze ethanol production from cassava processing residues and to evaluate its impact on the Brazilian energy matrix, replacing first generation biofuels.

\section{Materials and Methods}

\subsection{Materials and Pre-Treatment}

This study was conducted at different stages and laboratories, the first stage (preparation of the samples, hydrolysis and fermentation) took place in the laboratory of biotechnology and physics of soil of the State University of Western Paraná, Campus Cascavel, the second and final stage (Distillation), was held in the Analytical Chemistry laboratory of the State University of Western Paraná, Campus Toledo.

The raw material used is characterized as cassava processing waste, also known as bagasse or cassava bran. The material was given by different cassava starch manufacturers, namely: Fecularia LAR, in the municipality of Missal/Parana, Industry Amidos Mundo Novo, located in the city of Novo Mundo/Mato Grosso do Sul, MCR Amidos located in Mercedes/PR and Horizonte Amidos located in Marechal Candido Rondon/PR.

The moisture content of the bagasse was determined using an oven at $110^{\circ} \mathrm{C}$ for $24 \mathrm{~h}$. For the determination of ash (\%) grease matter (\%), and fiber (\%), AOAC-Official Methods of Analysis (1995) were used. The protein content was determined by converting the total $\mathrm{N}$ content in protein by using the factor 6.25. The starch content was calculated by the difference of the other components of the sample (moisture, ash, protein, raw fat, fiber, and total soluble sugar) under the rules of the Adolfo Lutz Institute (2005).

\subsection{Enzymatic Hydrolysis}

The enzymes used are produced, purified and standardized by the manufacturer for industrial application of food grade. The enzymes used were provided by the companies Science Pro (Araucaria, Brazil) and LNF-Latin American obtained from Novozymes ${ }^{\circledR}$ Latin America manufacturer (Araucária, Brazil). Enzymes used were: Hydrolytic (Alpha-amylase) and Saccharifying (Amyloglucosidases). The strain used was Saccharomyces cerevisiae from the LNF.

As the material has a wet and disintegrated structure, it was necessary to perform moisture control factor using greenhouse and heating it to $110^{\circ} \mathrm{C}$ for $24 \mathrm{~h}$. After checking the moisture content of each sample, dilution was performed in distilled water. Six erlemeyers were used with $20 \mathrm{~g}$ of dry bagasse for each treatment, a total of 24 flasks.

To carry out hydrolysis, the solid material was suspended in distilled water. For measurement of $\mathrm{pH}$, a microprocessor phmetrer bench was used, and the $\mathrm{pH}$ was adjusted with $0.06 \mathrm{~mol}$ sodium hydroxide solution. The samples were heated in a water bath to $45^{\circ} \mathrm{C}$, and Liquozyme ${ }^{\circledR}$ (Araucaria, Brazil) enzyme was added in cassava mass. Subsequently, the temperature was raised to $90^{\circ} \mathrm{C}$. The hydrolysis was carried out for $60 \mathrm{~min}$. under mechanical agitation of $200 \mathrm{rpm}$ and a constant temperature of $60^{\circ} \mathrm{C}$.

After dextrinization, the samples were subjected to a bath in order to reduce the temperature at $36{ }^{\circ} \mathrm{C}$, and the $\mathrm{pH}$ of the dispersion was adjusted to 5.1 to 5.5 with 0.06 mol sodium hydroxide 
and heated again to $60^{\circ} \mathrm{C}$. After the temperature reached $60{ }^{\circ} \mathrm{C}$, a suspension of amyloglucosidase enzyme was added and subjected again by mechanical agitation for a predetermined time of one hour at $100 \mathrm{rpm}$. Filtering of the hydrolyzate material was performed for removing impurities (fiber) using a vacuum pump, Buchner funnel and kitassato.

\subsection{Fermentation and Distillation}

Each assay was performed in sequence, and the hydrolysates were frozen for later fermentation and distillation. For the fermentation of the yeast strain, Saccharomyces cerevisiae was used. The quantity used was $100 \mathrm{~g} / \mathrm{L}$ of must. In addition, 10\% fermentation volume was used in water at $35{ }^{\circ} \mathrm{C}$ for diluting the yeast for $30 \mathrm{~min}$. before adding samples for fermentation. The samples were subjected to constant agitation of $100 \mathrm{rpm}$ and $30{ }^{\circ} \mathrm{C}$ for $24 \mathrm{~h}$. Then, we realized the wine filtration process.

\subsection{Analysis Methods}

Infrared spectrometric analysis was performed prior to analysis of 24 samples, making it possible to obtain the spectra and highlighting the best samples for each treatment with the samples that have been selected with major peaks for the distillation procedure. The step of obtaining the wine was carried out by simple distillation at a concentration of $10 \%$. The monitoring of temperature using a digital thermometer was performed.

For analysis of distilled portions, infrared spectrometric analysis was used to verify the presence of ethanol by medium infrared, with a wavelength of 1600-1800 nm. Figure 1 represents systematically the process as a whole, for obtaining ethanol.

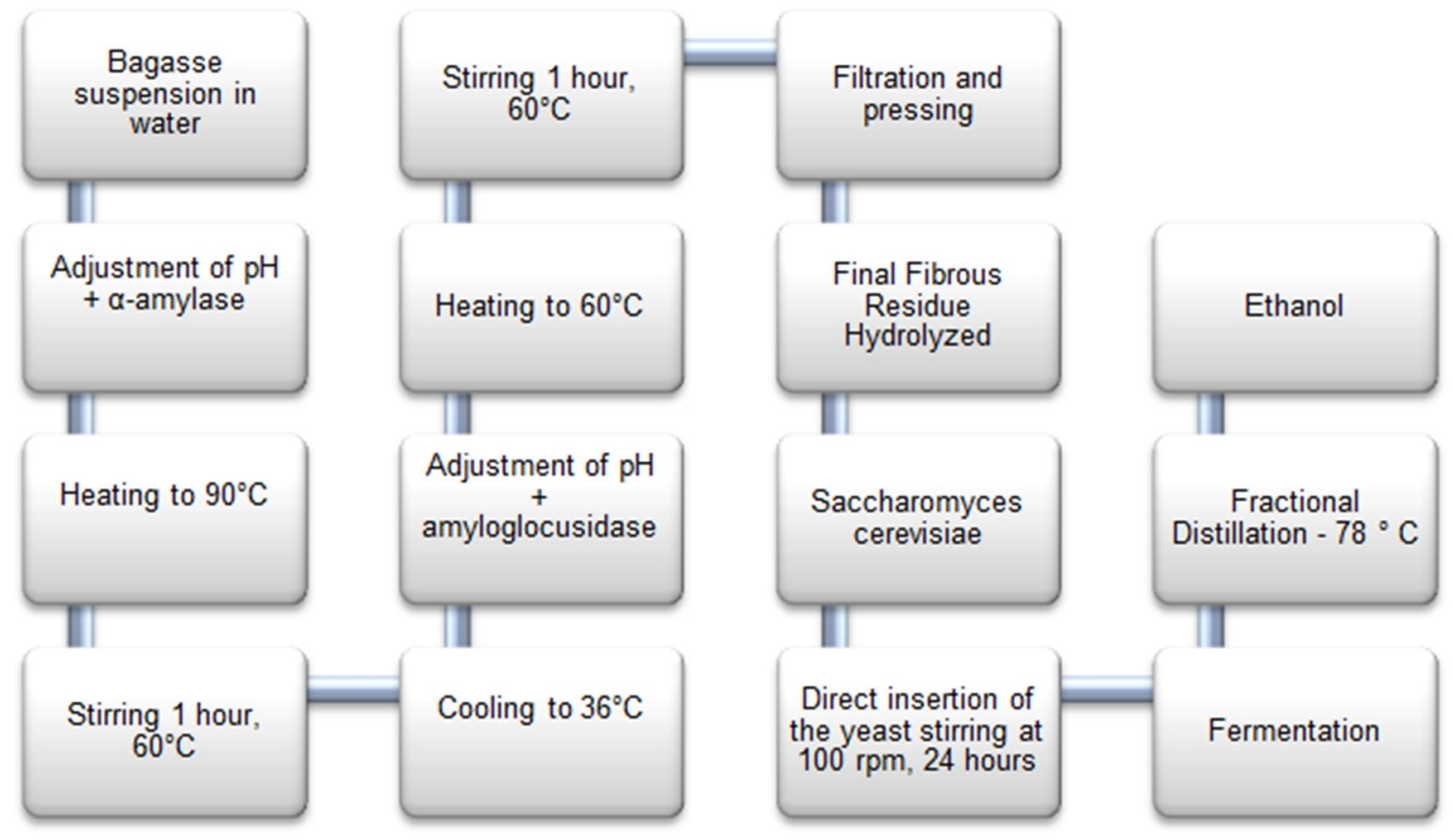

Figure 1. This represents systematically the process as a whole, for obtaining ethanol.

\section{Results and Discussion}

\subsection{Potential for Ethanol Production}

Before and after drying treatment, samples A3 and A4 visually presented darker staining when compared to others revealing the differences in industrial processes. In Table 1, the values obtained from the compositional analysis of cassava bagasse are displayed. 
Table 1. Physical and chemical characterization of samples before hydrolysis.

\begin{tabular}{ccccccccc}
\hline Samples & $\begin{array}{c}\text { Starch } \\
\mathbf{( \% )}\end{array}$ & $\begin{array}{c}\text { Raw Fiber } \\
(\mathbf{g} / \mathbf{1 0 0} \mathbf{~ g})\end{array}$ & $\begin{array}{c}\text { Protein } \\
(\mathbf{g} / \mathbf{1 0 0} \mathbf{g})\end{array}$ & $\begin{array}{c}\text { Sugars } \\
(\mathbf{g} / \mathbf{1 0 0} \mathbf{~ g})\end{array}$ & $\begin{array}{c}\text { Grease Matter } \\
(\mathbf{g} / \mathbf{1 0 0} \mathbf{g})\end{array}$ & $\mathbf{p H}$ & $\begin{array}{c}\text { Humidity } \\
\mathbf{( \% )}\end{array}$ & $\begin{array}{c}\text { Ash } \\
(\mathbf{g} / \mathbf{1 0 0} \mathbf{g})\end{array}$ \\
\hline A1 & 64.80 & 3.42 & 0.49 & 8.30 & 0.21 & 4.31 & 87.14 & 0.23 \\
A2 & 59.90 & 3.85 & 0.53 & 6.61 & 0.20 & 4.45 & 89.29 & 0.29 \\
A3 & 64.10 & 6.07 & 0.90 & 8.04 & 0.20 & 4.50 & 88.70 & 0.12 \\
A4 & 68.30 & 3.94 & 0.52 & 8.24 & 0.01 & 4.91 & 86.75 & 0.23 \\
Mean & 64.27 & 4.32 & 0.61 & 7.79 & 0.15 & 4.54 & 87.97 & 0.21 \\
\hline
\end{tabular}

The bagasse used had approximately $88 \%$ average moisture content. [10] Reported that starch-fibrous material has a large water retention capacity, and often the moisture content of the pulp leaving the process is higher than $80 \%$. In accordance with [11], each ton of processed root yields approximately $930 \mathrm{~kg}$ of bagasse with $85 \%$ moisture content.

These values are specific for many bagasse cassava, as there are root variations having different chemical compositions [12]. It was observed that the residual starch concentrations are similar (Table 1). The soluble sugars were also similar, except for the sample from A2, which showed a lower value compared with other samples. The similarity between the other samples is probably due to the action of similar degrading microorganisms, indicating the possible need to use additives for fermentation.

The major component, starch, comprised approximately $64 \%$ on average and was highest in A4, with a value of $68.30 \%$. The content of starch in the bagasse is within the average value obtained by different authors, ranging from $47.10 \%$ [13] to $65.37 \%$ [14].

According to Table 1, the levels of various chemical components found may be comparable with the results obtained by $[9,15]$. where the values found were as follows: $65.16 \%$ moisture in the humid matter, $3.0 \%$ protein, $0.30 \%$ grease matter, $2.6 \%$ fiber, $2.4 \%$ ash, and $8.2 \%$ sugar. The presence of low concentrations of protein and fatty matter found favors the fermentation process considerably by reducing foaming. Table 2 shows the values obtained after the hydrolysis process.

Table 2. Physical and chemical characterization of samples after hydrolysis.

\begin{tabular}{ccccccccc}
\hline Sample & $\begin{array}{c}\text { Humidity } \\
\mathbf{( \% )}\end{array}$ & $\begin{array}{c}\text { \% Total } \\
\text { Solids }\end{array}$ & $\begin{array}{c}\text { g/Total } \\
\text { Solids }\end{array}$ & $\begin{array}{c}\text { Initial } \\
\mathbf{p H}\end{array}$ & $\begin{array}{c}\text { Final } \\
\mathbf{p H}\end{array}$ & $\begin{array}{c}\text { Mass } \\
\mathbf{( \% )}\end{array}$ & $\begin{array}{c}\text { Volume before } \\
\text { Hydrolysis }(\mathbf{m L})\end{array}$ & $\begin{array}{c}\text { Volume after } \\
\text { Hydrolysis }(\mathbf{m L})\end{array}$ \\
\hline A1 & 64.19 & 35.81 & 7.16 & 6.15 & 5.14 & 27.13 & 150 & 130.67 \\
A2 & 68.88 & 31.12 & 6.22 & 5.98 & 5.23 & 29.52 & 150 & 124.00 \\
A3 & 68.59 & 31.41 & 6.28 & 5.94 & 5.37 & 29.24 & 150 & 132.67 \\
A4 & 75.90 & 24.10 & 4.82 & 6.22 & 5.39 & 32.52 & 150 & 124.17 \\
\hline
\end{tabular}

Temperature adopted $60^{\circ} \mathrm{C}$, density $1.13 \mathrm{~g} / \mathrm{mL}$, residence time $1 \mathrm{~h}$, and a volume used of $20 \mathrm{~g}$ of substrate. Through infrared spectrometric analysis, it was found that various samples showed similarities in the spectra. As described above, the samples were distilled at $10 \%$ concentration utilizing only $5 \mathrm{~mL}$ from $50 \mathrm{~mL}$; therefore, treatments that showed the highest amount of ethanol in distilled material were $\mathrm{A} 2$ and $\mathrm{A} 4$, respectively having $2.4 \mathrm{~mL}$ and $2.65 \mathrm{~mL}$ of ethanol from $5 \mathrm{~mL}$ of solution. A1 had a value of $0.63 \mathrm{~mL}$ ethanol from distillation. Figure 2 indicates the curves obtained in the analysis of infrared spectrometry. 


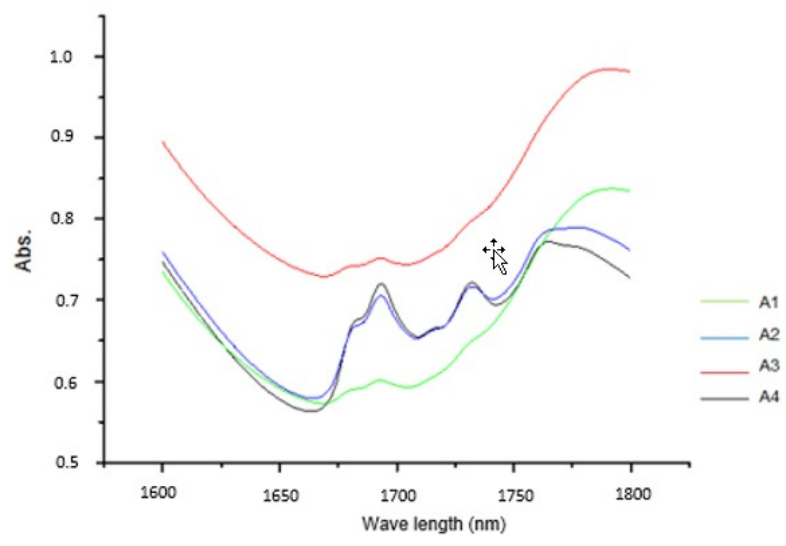

Figure 2. Chart showing absorption spectra of the solutions A, B, C, and D to the solutions distilled to $10 \%$ by volume.

The solutions of A1, A2, and A4 have baselines close to the standard solutions and can be analyzed using the adjusted straight-line method, providing the concentrations of $\mathrm{A} 1$ as $12.6 \%, \mathrm{~A} 2$ as $48.5 \%$, and $\mathrm{A} 4$ as $53.3 \%$. The A3 solution had a very different baseline from the standard solution; therefore, its analysis was difficult. However, by spectral comparison between the solutions of A3 and A1, the concentrations are expected to be close to each other, obtaining a value of approximately $12 \%$ for $\mathrm{A} 3$.

The ethanol values obtained were found to be directly related to the amount of starch present in the sample, as can be seen in Table 3. It is noteworthy that A2 presented greater efficiency in ethanol production compared with $\mathrm{A} 1$ and $\mathrm{A} 3$, considering the starch percentage.

Table 3. Values after distillation.

\begin{tabular}{cccccccc}
\hline Treatment & $\begin{array}{c}\text { Starch } \\
\mathbf{( \% )}\end{array}$ & $\begin{array}{c}\text { Ethanol } \\
\mathbf{( \% )}\end{array}$ & $\begin{array}{c}\text { Ethanol } \\
\mathbf{( m L / k g )}\end{array}$ & $\begin{array}{c}\text { Ethanol } \\
\text { Yield (\%) }\end{array}$ & $\begin{array}{c}\text { Fibrous } \\
\text { Residue (\%) }\end{array}$ & $\begin{array}{c}\text { Reducing } \\
\text { Sugars (g/100 g) }\end{array}$ & $\begin{array}{c}\text { Reducing } \\
\text { Sugars (\%) }\end{array}$ \\
\hline A1 & 64.80 & 12.60 & 103.48 & 12.06 & 27.13 & 2.43 & 0.02 \\
A2 & 59.90 & 48.50 & 368.21 & 48.50 & 29.52 & 2.27 & 0.02 \\
A3 & 64.10 & 12.00 & 97.49 & 12.00 & 29.24 & 2.35 & 0.02 \\
A4 & 68.30 & 53.30 & 461.39 & 53.00 & 32.52 & 3.65 & 0.04 \\
Mean & 64.28 & 31.60 & 251.45 & 31.00 & 29.60 & 2.68 & 0.03 \\
\hline
\end{tabular}

The A4 had higher conversion of ethanol at $53 \%$, slightly below the values reported by other authors, such as [16]. wherein the ethanol production obtained from cassava pulp was $78.6 \%$. This oscillation in values in relation to ethanol production is directly related to the different process conditions that the samples have been subjected to, from the efficiency of the centrifuges to the storage model. In Table 4, we can observe the comparison between ethanol production potential from different substrates.

Table 4. Potential of ethanol production from different substrates.

\begin{tabular}{cccc}
\hline Substrates & Starch Concentration (\%) & Ethanol Production $(\mathbf{g} / \mathbf{g})$ & Authors \\
\hline Cassava bagasse & 64 & 0.21 & - \\
Corn & $69[17]$ & $0.32[18]$ & {$[17,18]$} \\
Wheat & $66[17]$ & $0.31[18]$ & {$[17,18]$} \\
Cane bagasse & $15[19]$ & $0.11[12]$ & {$[12,19]$} \\
Corn stover & 64 & $0.26[20]$ & {$[20]$} \\
\hline
\end{tabular}

These variables make it possible to miss a part of starch, as the samples showed acidity, concluding therefore that part of the starch was converted to organic acids.

From the values described in Table 4, about $251 \mathrm{~mL} / \mathrm{kg}$, that is, $0.25 \mathrm{~m}^{3}$ of ethanol per ton of cassava bagasse, were obtained. The concentration of ethanol was $31 \%$ in average. [21] obtained 
by distilling $16 \mathrm{~mL}$ of cassava residue, about $32.4 \%$ ethanol at a temperature of $32{ }^{\circ} \mathrm{C}$. The ethanol yield obtained was $31 \%$ on average, according to [22] who carried out research using two strains of Saccharomyces cerevisiae of non-manioc.

\subsection{Second Generation Ethanol from Brazil}

According to the Energy Research Company-EPE [23] by 2030, Brazil will produce approximately 2 billion liters of second generation ethanol, considering a projection for the only two plants installed in Brazil. The Union of Producers of Sugar Cane-UNICA releases monthly the production of anhydrous and hydrated etanol. In Figure 3, the comparison between the potential of ethanol production from cassava bagasse (considering the volumes of bagasse generated) and the production of first generation ethanol produced in the months of May to December 2017 can be observed.

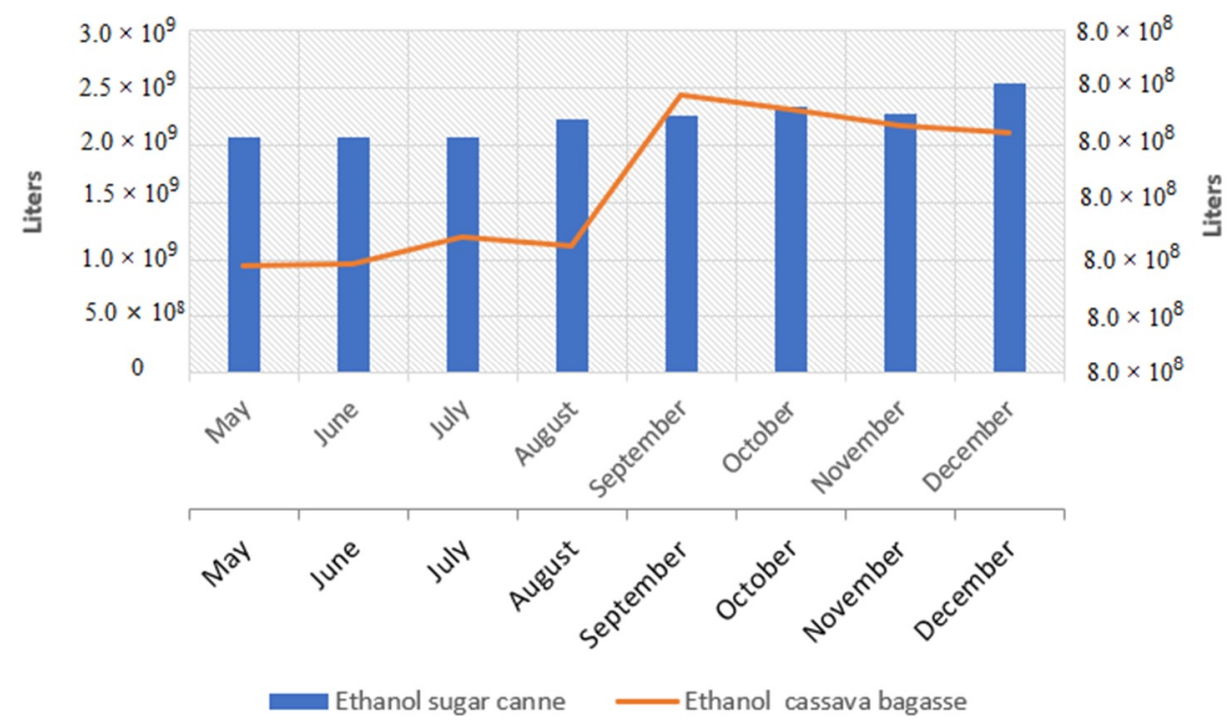

Figure 3. Comparison of the production of first and second generation etanol; source: UNICA-Union of Producers of Sugar Cane, 2018.

With the volume generated from the cassava meal, it would be possible to produce about 9 million $\mathrm{m}^{3}$ of second generation etanol. This value inserted in the Brazilian energy matrix could replace about $24 \%$ of the first generation ethanol produced from sugarcane sugar. The decision regarding second generation ethanol production should be made considering the opportunity prices for the different biomass derived products (ethanol and other biofuels, bioelectricity and sugar, among others) [3].

Therefore, the total use of this biomass received by the industry, including generated residues, is important for the industrial economy balance. In addition, the use of this agro-industrial waste as a carbon source for another process helps to solve the pollution problems. Each ton of cassava contains $211.2 \mathrm{~kg}$ of native starch and, after industrial processing, 115.5-132.0 kg (Chavalparit and Ongwandee, 2009) are generated as solid waste.

According to [24] if the cassava bagasse generated in Brazil in 2014 (about 3.5 million tons, dry basis) is considered, it would have the potential to produce 866.6 million liters of additional ethanol, corresponding to an increase of $3.04 \%$ of total ethanol production in Brazil during the same period, which was 28.48 billion liters, according to UNICA (2014).

Second generation ethanol on an industrial scale depends primarily on political factors and, in a second stage, on technical achievements. In fact, although the technique makes the industrial scale feasible, and constitutes a major challenge, the evolution of second generation ethanol in the industry as a whole depends crucially on policies and strategic decisions, which include the promotion of technology and policies to create artificial markets [25]. 


\section{Conclusions}

- Within the experimental conditions, the results showed that cassava bagasse showed starch content with an average of $64 \%$, making it as an efficient raw material for second-generation ethanol production process.

- There was an average ethanol production potential of $0.25 \mathrm{~m}^{3} /$ ton of cassava bagasse.

- This material has potential features that make it an interesting biomass for energy matrix enlargement.

- It is important to note that using cassava bagasse to produce second generation ethanol can prevent future competition for land use between ethanol production and food production, thereby enabling an increase in ethanol production without causing an increase in cassava.

Author Contributions: Conceptualization, Investigation, Methodology, Data Curation and Validation, contributed by D.G.M. and A.F.; Formal Analysis, contributed by R.B.; Visualization and Supervision, contributed by R.B., A.F. and K.R.d.F.Z.

Funding: This research received no external funding.

Conflicts of Interest: The authors declare no conflict of interest.

\section{References}

1. Teixeira, E.M.; Curvelo, A.A.S.; Corrêa, A.C.; Marconcini, J.M.; Glenn, G.M.; Mattoso, L.H.C. Properties of thermoplastic starch from cassava bagasse and cassava starch and their blends with poly (lactic acid). Industrial crops and products. Ind. Crops Prod. 2012, 37, 61-68. [CrossRef]

2. Pandey, A.; Soccol, C.R.; Nigam, P.; Soccol, V.T.; Vandenberge, L.P.S.; Mohan, R. Biotechnological potential of agro-industrial residues II: Cassava bagasse. Bioresour. Technol. 2000, 74, 81-87. [CrossRef]

3. Escaramboni, B.; Núnez, E.G.F.; Carvalho, A.F.A.; Neto, P.O. Ethanol biosynthesis by fast hydrolysis of cassava bagasse using fungal amylases produced in optimized conditions. Ind. Crops Prod. 2018, 112, 368-377. [CrossRef]

4. Carpio, L.G.T.; Souza, F.S. Optimal allocation of sugarcane bagasse for producing bioelectricity and second generation ethanol in Brazil: Scenarios of cost reductions. Renew. Energy 2017, 111, 771-780. [CrossRef]

5. Cardona, C.A.; Quintero, J.A.; Paz, I.C. Production of bioethanol from sugarcane bagasse: Status and perspectives. Bioresour. Technol. 2010, 101, 4754-4766. [CrossRef] [PubMed]

6. Dias, M.O.S.; Cunha, M.P.; Jesus, C.D.F.; Rocha, G.J.M.; Pradella, J.G.C.; Rossell, C.E.V.; Filho, R.M.; Bonomi, A. Second Generation ethanol in Brazil: Can it compete with electricity production? Bioresour. Technol. 2011, 102, 8964-8971. [CrossRef] [PubMed]

7. UNICA. União dos Produtores de Cana de Açúcar. Available online: www.unica.com.br/unicadata (accessed on 12 August 2018).

8. Cavalett, O.; Chagas, M.F.; Junqueira, T.L.; Watanabe, M.D.; Bonomi, A. Environmental impacts of technology learning curve for cellulosic ethanol in Brazil. Ind. Crops Prod. 2017, 106, 31-39. [CrossRef]

9. Cereda, M.P. Caracterização, usos e tratamentos de resíduos da industrialização da mandioca.Centro de raízes tropicais. Botucatu Centro de Raízes Tropicais 1996, 5, 56.

10. Cranshak, J.; Andrade, J. Caracterização físico-química de bagaço de mandioca in natura e após tratamento hidrolítico. Rev. Bras. Tecnol. Agroind. 2011, 5, 427-441.

11. Raupp, D.; Moreira, S.; Banzatto, D.; Sgarbieri, V. Composição e propriedades fisiológico—Nutritivas de uma farinha rica em fibra insolúvel obtida do resíduo fibroso de uma fecularia de mandioca. Ciênc. Tecnol. Aliment. 1999, 19, 205-210. [CrossRef]

12. Saitto, I.; Cabello, C. Produção de etanol a partir de hidrolisado obtido por tratamento hidrotérmico de farelo de mandioca. Rev. Energ. Agric. 2006, 21, 34-44.

13. Zuh, F. Composition, structure, physicochemical properties, and modifications of cassava starch. Carbohydr. Polym. 2015, 122, 456-480.

14. Srinnorakutara, T.; Kaewvimol, L.; Saengow, L. Apprach of cassava waste pretreatments for fuel etanol production in Thailand. J. Sci. Res. 2006, 31, 77-84. 
15. Wosiacki, G.; Cereda, M. Valorização de resíduos do processamento de mandioca. Agrar. Sci. Eng. 2002, 8, 27-43.

16. Camili, E.A. Parâmetros Operacionais do Processo de Produção de Etanol a Partir da Polpa de Mandioca. Ph.D. Thesis, Universidade Estadual Paulista "Julio de Mesquita Filho", São Paulo, Brazil, 2010; pp. 1-131.

17. Balat, M.; Balat, H. Recent trends in global production and utilization of bio-ethanol fuel. Appl. Energy. 2009, 86, 2273-2282. [CrossRef]

18. Wang, M.; Han, J.; Dunn, J.B.; Cai, H.; Elgowainy, A. Well-to-wheels energy use and Greenhouse gas emissions of etanol from corn, sugarcane and cellulosic biomass for US use. Environ. Res. Lett. 2012, 7, 1-13. [CrossRef]

19. Dias, M.O.S.; Cunha, M.P.; Maciel Filho, R.; Bonomi, A.; Jesus, C.D.F.; Rossell, C.E.V. Simulation of integrated first and second generation bioethanol production from sugarcane: comparison between different biomass pretreatment methods. J. Ind. Microbiol. Biotechnol. 2011, 38, 955-966. [CrossRef] [PubMed]

20. Kadam, K.L.; McMillan, J.D. Availability of corn stover as a sustainable feed-stock for bioethanol production. Bioresour. Technol. 2003, 88, 17-25. [CrossRef]

21. Emeka, E.E.; Chales, O.O.; Anthony, O.C. Utilization of cellulosic cassava waste for bio-ethanol production. J. Environ. Chem. Eng. 2015, 3, 2797-2800.

22. Ajibola, F.O.; Edema, M.O.; Oyewole, O.B. Enzymatic Production of Ethanol from Cassava Starch Using Two Strains of Saccharomyces Cerevisiae. Niger. Food J. 2012, 30, 114-121. [CrossRef]

23. Energy Research Company-EPE. Report of Ethanol Production in Brazil. Available online: http:/ / www.epe. gov.br (accessed on 5 July 2018).

24. Dias, M.O.S.; Junqueira, T.L.; Cavallet, O.; Cunha, M.P.; Jesus, C.D.F.; Mantelatto, P.E.; Rossell, C.E.V.; Filho, R.M.; Bonomi, A. Cogeneration in integrated first and second generation ethanol from sugarcane. Chem. Eng. Res. Des. 2013, 91, 1411-1417. [CrossRef]

25. Raele, R.; Boaventura, J.M.G.; Fischmann, A.A.; Sarturi, G. Scenarios for the second generation ethanol in Brazil. Technol. Forecast. 2014, 87, 205-223. [CrossRef] 